\title{
Effects of close-up dietary energy level and supplementing rumen-protected lysine on energy metabolites and milk production in transition cows
}

\author{
D. D. Girma, ${ }^{1 *}$ L. Ma,${ }^{1,2 *}$ F. Wang, ${ }^{1}$ Q. R. Jiang, ${ }^{1}$ T. R. Callaway, ${ }^{3}$ J. K. Drackley, ${ }^{4}$ and D. P. $B u^{1,2,5} \dagger$ \\ ${ }^{1}$ State Key Laboratory of Animal Nutrition, Institute of Animal Science, Chinese Academy of Agricultural Sciences, Beijing 100193, P.R. China \\ ${ }^{2}$ Chinese Academy of Agricultural Sciences-World Agroforestry Centre (CAAS-ICRAF) Joint Laboratory on Agroforestry \\ and Sustainable Animal Husbandry, World Agroforestry Centre, East and Central Asia, Beijing 100193, China \\ ${ }^{3}$ Department of Animal and Dairy Science, University of Georgia, Athens 30602-2771 \\ ${ }^{4}$ Department of Animal Sciences, University of Illinois, Urbana 61801 \\ ${ }^{5}$ Hunan Co-Innovation Center of Safety Animal Production, Changsha, Hunan 410128, China
}

\section{ABSTRACT}

The objective of this study was to investigate the effects of dietary energy levels and rumen-protected lysine supplementation on serum free fatty acid levels, $\beta$-hydroxybutyrate levels, dry matter (DM) intake, and milk production and composition. Treatments were arranged in a $2 \times 2$ factorial design with 2 dietary energy levels [high net energy for lactation $\left(\mathrm{NE}_{\mathrm{L}}\right)=1.53 \mathrm{Mcal} /$ $\mathrm{kg}$ of $\mathrm{DM}$ vs. low $\mathrm{NE}_{\mathrm{L}}=1.37 \mathrm{Mcal} / \mathrm{kg}$ of $\mathrm{DM}$; HE vs. LE) fed either with rumen-protected lysine (bypass lysine; $40 \mathrm{~g} /$ cow per day) or without rumen-protected lysine (control). Sixty-eight third-lactation Holstein dairy cows entering their fourth lactation were randomly allocated to 4 treatments groups: HE with bypass lysine, HE without bypass lysine, LE with bypass lysine, and LE without bypass lysine. Groups were balanced based upon their expected calving date, previous milk yields, and body condition score. All cows were fed the same diet $\left(\mathrm{NE}_{\mathrm{L}}=1.34 \mathrm{Mcal} / \mathrm{kg}\right.$ of $\left.\mathrm{DM}\right)$ during the dry period prior to the trial. Rumen-protected lysine was top-dressed on a total mixed ration to deliver $9.68 \mathrm{~g} / \mathrm{d}$ of metabolizable lysine to pre- and postpartum cows. After calving, all cows received the same TMR (1.69 $\mathrm{Mcal} / \mathrm{kg}$ of DM). Blood samples were collected at -21 , $-14,-7,0,3,7,14$, and $21 \mathrm{~d}$ relative to calving, and free fatty acids and $\beta$-hydroxybutyrate concentrations were measured. Amount of feed offered and orts were collected and measured for individual cows $4 \mathrm{~d} /$ wk. Milk samples were collected once per week following calving, and milk composition was analyzed. Feeding high $\mathrm{NE}_{\mathrm{L}}$ to close-up cows decreased the concentrations

Received November 7, 2018.

Accepted April 8, 2019.

*These authors contributed equally to this work.

†Corresponding author: budengpan@126.com of free fatty acid and $\beta$-hydroxybutyrate in prepartum cows but not in postpartum cows. Addition of rumenprotected lysine increased postpartum DM intake, and decreased serum free fatty acid and $\beta$-hydroxybutyrate concentrations. Neither energy nor rumen-protected lysine supplementation nor their interaction affected milk yield or fat or lactose yields. However, cows in the group receiving $\mathrm{HE}$ with bypass lysine tended to produce more milk compared with other groups and had a lower blood $\beta$-hydroxybutyrate concentration postpartum. These results indicate that feeding a high-energy diet together with rumen-protected lysine improved DM intake and lowered serum free fatty acid and $\beta$-hydroxybutyrate concentrations in transition cows.

Key words: dietary energy, rumen-protected lysine, $\beta$-hydroxybutyrate, transition cow

\section{INTRODUCTION}

As cows transition from the gestation period to lactation (3 wk before to $3 \mathrm{wk}$ after calving), they undergo significant physiological and immunological changes, and the incidence of many metabolic disorders is at its highest during early lactation (Drackley, 1999). During the transition period, it is difficult or impossible to meet the increased nutrient demands of cattle because of restricted feed intake, which results in cows mobilizing their fat stores as well as muscle tissue to compensate for the dietary nutrient deficit. Grummer et al. (2004) reported that the daily DMI of transition cows was reduced by up to $30 \%$ and was accompanied by an increased energy demand due to the onset of lactation, leading to a negative energy balance. Most high-producing dairy cows usually face some degree of negative energy balance, which is accompanied by immune suppression around parturition (Goff, 2006) and is associated with a variety of production diseases (Drackley, 1999). 
The transition period is a key phase in the lactation cycle and requires intensive dietary management. Feeding higher energy diets to cows during the dry and close-up periods could improve body condition, but it does not reduce the degree of adipose tissue mobilization during the transition period; it only exacerbates the negative energy balance during early lactation (Graugnard et al., 2012; Vailati-Riboni et al., 2017). Studies have demonstrated that overfeeding even a moderateenergy diet resulted in greater metabolic stress and incidence of disorders (such as ketosis and fatty liver) in postpartum cows, which can have a profound negative impact on milk yield even before an official diagnosis can be made (Douglas et al., 2006). Although highenergy diets predispose postpartum cows to experience a more negative energy balance, cows fed a precalving high-energy diet (1.7 Mcal $/ \mathrm{kg}$ of DM) had a more positive energy balance, higher plasma concentrations of glucose and insulin, a $19.8 \%$ increase in DMI, and lower concentrations of plasma nonesterified fatty acids (NEFA) on d -7 relative to calving compared with cows fed a low-energy (1.58 Mcal/kg of $\mathrm{DM})$ ration (Rabelo et al., 2003, 2005).

To reduce the risk of metabolic disorders, it is important to increase energy intake, but this practice carries some associated risks. Carnitine is a methylated form of lysine (Shug et al., 1982), which acts as a buffer for acetyl residues originating from fat mobilization and thereby reduces ketone body formation and plasma levels of BHB (Jacobs, 2002). Carnitine is important for oxidation of long-chain fatty acids, regulation of ketosis, support of the immune system, and enhancement of the antioxidant system (Citil et al., 2009; Pirestani et al., 2011). Supplemental L-carnitine has been shown to potentially decrease or prevent liver triacylglycerol accumulation in dairy cows (Carlson et al., 2006).

Because lysine is largely degraded by ruminal microbes, supplementation of free lysine is an inefficient strategy to increase the supply of lysine that serves as the carbon backbone for carnitine synthesis and performs other functions (Robinson et al., 2006; Vaz and Wanders, 2002). Thus, technologies that protect lysine from ruminal microbial degradation have emerged (Ardaillon and Franzoni, 1992). However, the interaction of precalving energy and rumen-protected lysine (RPL) during the transition period in dairy cows has not been well explored.

Therefore, the inclusion of lysine is a critical factor in the manipulation of the dietary energy content of TMR fed to close-up cows to control their negative energy balance. In the present study, we hypothesized that providing transition cows with an increased level of energy and providing RPL would improve DMI, reduce serum free fatty acid (FFA) and BHB concentrations, and increase milk production during the transition period. The objective of the current study was to investigate the effects of close-up supplementation of dietary $\mathrm{NE}_{\mathrm{L}}$ levels (1.53 or $1.37 \mathrm{Mcal} / \mathrm{kg}$ of DM) and supplementation of RPL (0 or $40 \mathrm{~g} /$ cow per day) on FFA levels, BHB levels, DMI, and milk production and composition during the transition period in dairy cows.

\section{MATERIALS AND METHODS}

\section{Experimental Design and Experimental Cows}

All procedures were approved by the Animal Care and Use Committee of the Institute of Animal Science, Chinese Academy of Agricultural Sciences, Beijing. Cows in the same parity (third lactation) entering their fourth lactation were chosen based on BCS $\geq 3.25$ and $\leq 3.5$ (1-5 scale) from a large herd. The expected calving date of each cow was considered in selecting cows with similar expected calving dates and previous milk yield. All selected cows were balanced for their BCS, expected calving date, and previous milk yield $(13,679.65 \pm 2,370.4 \mathrm{~kg} 305 \mathrm{~d}$ milk yield, $P=0.80)$ before being randomly assigned to dietary treatment groups. A statistical power analysis was performed with an $\alpha=0.05$ and power $=0.90$, and the sample size needed with 0.4 effect size, projected using G power 3.1 software (Faul et al., 2009), was approximately 68 cows. The 68 selected cows were each randomly allocated to 1 of 4 dietary treatment groups $(\mathrm{n}=17$ in each group) arranged in a $2 \times 2$ factorial design using 2 dietary $\mathrm{NE}_{\mathrm{L}}$ levels (high energy, $\mathrm{NE}_{\mathrm{L}}=1.53 \mathrm{Mcal} / \mathrm{kg}$ of $\mathrm{DM}$ vs. low energy, $\mathrm{NE}_{\mathrm{L}}=1.37 \mathrm{Mcal} / \mathrm{kg}$ of $\mathrm{DM} ; \mathbf{H E}$ vs. $\left.\mathbf{L E}\right)$ and RPL added at the level of 0 (control) or $40 \mathrm{~g} / \mathrm{cow}$ per day (bypass lysine), respectively. Dietary treatments were arranged as $\mathrm{HE}$ with bypass lysine, $\mathrm{HE}$ without bypass lysine, LE with bypass lysine, and LE without bypass lysine.

\section{Dietary Treatment Rations and Cow Housing}

Before being fed the close-up HE or LE rations, all cows received the same diet $\left(\mathrm{NE}_{\mathrm{L}}=1.34 \mathrm{Mcal} / \mathrm{kg}\right.$ of $\mathrm{DM}$ ) during the dry period until $\mathrm{d}-21$ when cows were switched to either HE or LE rations until d 0 (calving date). After calving, all cows received the same lactation ration up to d $21\left(\mathrm{NE}_{\mathrm{L}}=1.69 \mathrm{Mcal} / \mathrm{kg}\right.$ of DM). The diets were formulated based on NRC (2001) to meet the nutrient requirements of a prepartum cow weighing $650 \mathrm{~kg}$ and consuming $12.01 \mathrm{~kg}$ of DM/d and a postpartum cow weighing $580 \mathrm{~kg}$, consuming $16.7 \mathrm{~kg}$ of $\mathrm{DM} / \mathrm{d}$, yielding $33 \mathrm{~kg} / \mathrm{d}$ of milk, $3.85 \%$ milk fat, 
Table 1. Chemical composition (\% of DM unless otherwise noted) and evaluation of prepartal and postpartal diets fed to multiparous Holstein cows with or without rumen-protected lysine (RPL) during the transition period ${ }^{1}$

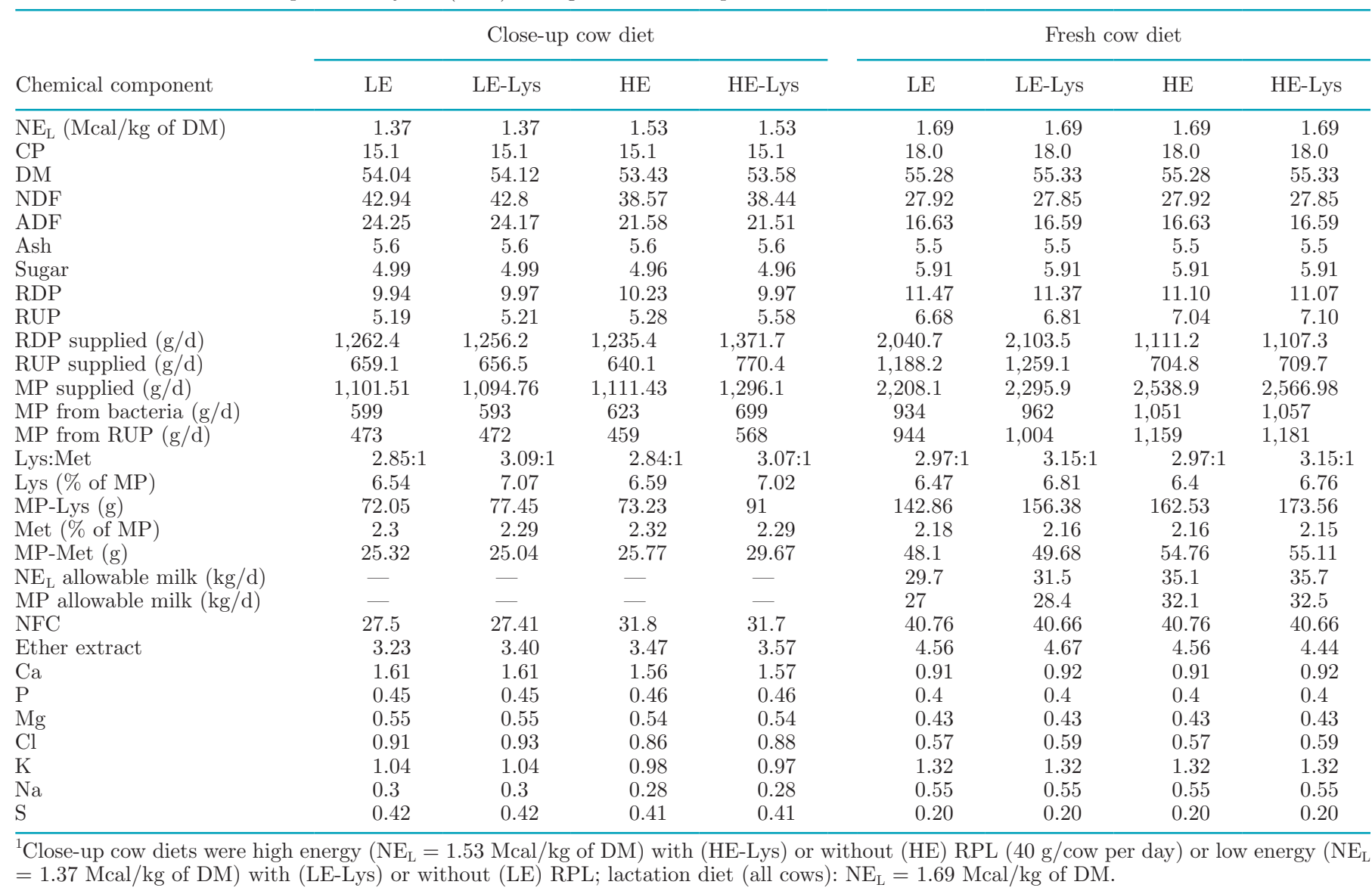

$3.07 \%$ of milk true protein, and 3.5 BCS. Dietary lysine and methionine were formulated based on NRC (2001) recommendations (6.9\% MP-Lys and $2.3 \%$ MP-Met) to meet the lysine-to-methionine ratio of $3: 1$ both for pre- and postpartum cows.

For the bypass lysine diets, RPL was top-dressed on the TMR once per day at a rate of $40 \mathrm{~g}$ of lysine/cow, using $50 \mathrm{~g}$ of ground corn as a carrier. Fifty grams of ground corn was also top-dressed to control diets. The RPL supplement (Ascor Chimici Srl, Beijing, China) contained $55 \%$ lysine with $44 \%$ bioavailability, and the pre- and postpartum lysine-fed cows therefore received $9.68 \mathrm{~g} / \mathrm{d}$ of metabolizable lysine. The values for RUP, RDP, Lys, and Met were evaluated using AMTS software (AMTS LLC, Groton, NY) based on the actual mean DMI and are presented in Table 1.

All experimental cows were housed in a ventilated enclosed barn during the experimental period and were individually fed their respective diets. Cows had access to stand and bedding areas until $3 \mathrm{~d}$ before expected parturition, when they were moved to individual maternity pens bedded with straw until parturition. After parturition, cows were individually fed a common lactation diet, with or without lysine supplementation. Total mixed rations were mixed daily and provided twice per day at 0600 and $1400 \mathrm{~h}$ (Tables 1 and 2). All cows were fed ad libitum with their respective dietary rations.

\section{Sampling, Measurements, and Analysis}

Feed offered and refusals were recorded each morning for 4 consecutive days per week. The TMR samples were frozen at $-20^{\circ} \mathrm{C}$ and composited monthly for analysis of DM, CP, NDF, ADF, and ash. Dry matter intake was determined by measuring feed provided and subtracting the orts remaining. Samples of TMR and orts from each treatment were analyzed for DM content by oven-drying at $60^{\circ} \mathrm{C}$ until they maintained a constant weight. The dried samples were ground through a 1-mm screen using a Cyclotec 1093 Mill (Tecator 1093, Tecator AB, Höganäs, Sweden) before analysis. Samples were further dried at $105^{\circ} \mathrm{C}$ for $2 \mathrm{~h}$ to determine the absolute DM, and chemical analyses were based on the final absolute DM. The $\mathrm{CP}(\mathrm{N} \times$ 
$6.25)$ content of feed samples was determined using the macro-Kjeldahl nitrogen test (AOAC International, 2000; method 976.05) with a Kjeltec digester 20 and a Kjeltec System 1026 distilling unit (Tecator AB). The contents of NDF and ADF were determined using procedure A by Van Soest et al. (1991) using heat-stable amylase (type XI-A of Bacillus subtilis; Sigma-Aldrich Corp., St. Louis, MO). The ash content was determined by incineration at $550^{\circ} \mathrm{C}$ overnight, and the $\mathrm{OM}$ content calculated (AOAC International, 2000; method 942.05). The ether extract content was determined us- ing a soxhlet system HT6 apparatus (Tecator AB) according to AOAC International (2000; method 920.39). Nonfiber carbohydrates were calculated according to the (NRC, 2001), and total sugars were quantified by incubation with invertase followed by measurement of reducing sugars (Martel et al., 2011).

\section{Blood Samples}

Duplicate blood samples of approximately $15-\mathrm{mL}$ were collected via a coccygeal vein from individual

Table 2. Ingredient composition of diets fed during close-up (-21 d to calving) and early lactation (calving to $21 \mathrm{~d})$ periods ${ }^{1}$

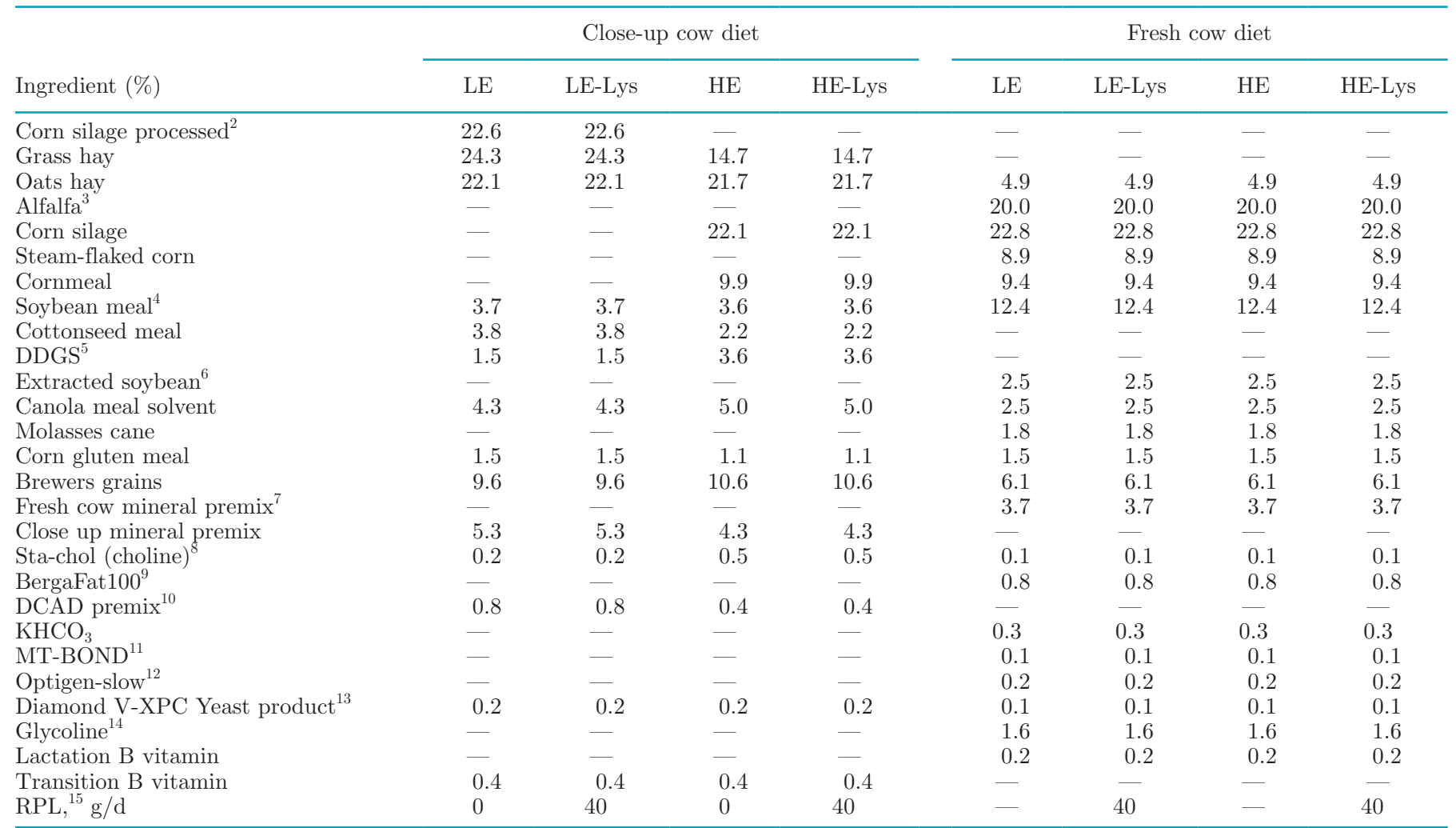

${ }^{1}$ Close-up cow diets were high energy $\left(\mathrm{NE}_{\mathrm{L}}=1.53 \mathrm{Mcal} / \mathrm{kg}\right.$ of $\left.\mathrm{DM}\right)$ with (HE-Lys) or without (HE) rumen-protected lysine (RPL; $40 \mathrm{~g} /$ cow per day) or low energy $\left(\mathrm{NE}_{\mathrm{L}}=1.37 \mathrm{Mcal} / \mathrm{kg}\right.$ of $\mathrm{DM}$ ) with (LE-Lys) or without (LE) RPL; lactation diet (all cows): $\mathrm{NE}_{\mathrm{L}}=1.69 \mathrm{Mcal} / \mathrm{kg}$ of $\mathrm{DM}$. After parturition, the same $40 \mathrm{~g} / \mathrm{cow}$ per day of RPL was supplemented for cows that had been fed RPL before calving.

${ }^{2} \mathrm{~A} 4.75$-mm sieve was used, and the kernel processing score was 50 to $70 \%$.

${ }^{3}$ Alfalfa hay was used to formulate the TMR.

${ }^{4}$ Soybean meal contained $89.1 \% \mathrm{DM}$ and $42.6 \% \mathrm{CP}$.

${ }^{5}$ DDGS $=$ distillers dried grains with solubles; nutrient-rich by-product of dry-milled ethanol production.

${ }^{6}$ Extracted soybean contained $92.6 \% \mathrm{DM}$ and $36.4 \% \mathrm{CP}$.

${ }^{7}$ Close-up and fresh cow mineral premix: $\mathrm{Ca}, \mathrm{P}, \mathrm{Mg}, \mathrm{K}, \mathrm{Na}, \mathrm{Cl}$, and $\mathrm{S}$.

${ }^{8}$ BCP Ingredients Inc., Verona, MO.

${ }^{9}$ BergaFat100 (Berg and Schmidt Nutrition Sdn. Bhd., Malaysia): bypass fats for ruminants providing extra energy without a carrier.

${ }^{10}$ Used to prevent hypocalcemia in close-up cows.

${ }^{11}$ MinTech (Tianjin) Minerals Co. Ltd., Tianjin, China.

${ }^{12}$ Nonprotein nitrogen source for ruminants (Alltech Inc., Nicholasville, KY).

${ }^{13}$ Diamond V XP yeast culture supplement (FD00365CHN-XP, Diamond V, Cedar Rapids, IA).

${ }^{14}$ Vitalac Co. Ltd., Carnoët, France.

${ }^{15}$ Ascor Chimici Srl (Beijing, China). 
cows at $0700 \mathrm{~h}$ daily on $\mathrm{d}-21,-14,-7,0,3,7,14$, and 21 relative to calving. All the blood samples were collected in serum separator tubes (Serum Clot Activator, Greiner Bio-one GmbH, Kremsmunster, Austria), and the samples were allowed to clot for a minimum of $25 \mathrm{~min}$ at $20^{\circ} \mathrm{C}$ and stored in the refrigerator overnight. The samples were then centrifuged at $3,000 \times g$ for 15 min at $4^{\circ} \mathrm{C}$ before separation of the serum. Blood serum was analyzed for BHB and FFA concentrations using commercial assay kits (Nanjing Jiancheng Bioengineering Institute, Nanjing Jiancheng Technology Co. Ltd., Nanjing, China) according to the manufacturer's instructions.

\section{Milk Samples}

Duplicate milk samples from individual cows were collected at 3 consecutive milkings and mixed based on the average milk production at each milking (morning, afternoon, and night; volume ratio of $4: 3: 3$ ) on d 7 , 14, and 21. One aliquot of milk was preserved with bronopol-B2 preservative (D \& F Control Systems Inc., Dublin, ON, Canada) at $4^{\circ} \mathrm{C}$ and subsequently analyzed for fat, protein, lactose, SCC, and MUN using a mid-infrared machine (Foss MilkoScan, Foss Food Technology Corp., Eden Prairie, MN).

\section{Body Condition Scoring}

Body condition scoring of experimental cows in all 4 dietary treatment groups was scored weekly from $\mathrm{d}-21$ through 21 relative to parturition day using a standard 5 -point scale $(1=$ emaciated, $5=$ obese). Body condition scores were always assessed by the same trained operative by palpating and visualizing individual body parts of the spinal column, the cranial coccygeal vertebrae, the tuber ischia, the tuber sacral, and the thigh region as described by Edmonson et al. (1989).

\section{Statistical Analysis}

The data for DMI, milk yield, milk composition, and blood parameters (FFA and BHB) were analyzed as a completely randomized design with repeated measures using PROC MIXED of SAS (version 9.2, SAS Institute Inc., Cary, NC). The MIXED statistical model used for analysis was as follows:

$$
\begin{aligned}
y_{i j k l}=\mu+ & L_{i}+E_{j}+L_{i j}+A_{i j k}+T_{1}+T L_{i l} \\
& +T_{j l}+T_{j} E_{i j l}+\varepsilon_{i j k l},
\end{aligned}
$$

where $y_{\mathrm{ijk}}$ was the dependent, continuous variable; $\mu$ was the overall mean; $L_{i}$ was the fixed effect of lysine
( $\mathrm{i}=$ with or without supplementary lysine); $\mathrm{E}_{\mathrm{j}}$ was the fixed effect of energy $(\mathrm{j}=1.37$ or $1.53 \mathrm{Mcal} / \mathrm{kg}$ of $\mathrm{DM})$; $\mathrm{A}_{\mathrm{ijk}}$ was the random effect of the kth cow in the ijth combination of lysine and energy; $\mathrm{T}_{1}$ was the fixed effect of time (day) of the experiment; the 2- and 3-way interactions of the time, lysine, and energy, all considered fixed; and $\varepsilon_{\mathrm{ijkl}}$ was the residual error. Serum FFA, BHB, DMI, milk yield, and composition were analyzed at various time point that were not equally spaced; hence, the covariance structure for the repeated measurements was modeled using the spatial power option. The Kenward-Roger option was used for computing the denominator degrees of freedom for testing hypotheses. All experimental cows grouped according to dietary treatment rations were carefully selected and balanced in BCS, previous milk yield, and expected calving date and had the same parity (third lactation) at the start of the trial. We did not see any significant difference in these variables at the beginning of the study, so we did not include these variables as covariates in statistical analysis. Least squares means were compared using LSD, and statistical differences were declared significant at $P \leq 0.05$. Tendencies were determined at $P \leq$ 0.10 .

\section{RESULTS AND DISCUSSION}

\section{Pre- and Postpartum DMI}

Main effects of precalving energy density, RPL, time, and their interactions on DMI, FFA, BHB, BCS, milk yield, and milk composition are summarized in Tables 3 and 4 . The dietary energy levels in this trial were formulated based on the NRC (2001) recommendations of 1.54 to $1.62 \mathrm{Mcal} / \mathrm{kg}$ of DM for the close-up period.

In the present study, the precalving HE diet (1.53 $\mathrm{Mcal} / \mathrm{kg}$ of DM) significantly increased DMI by $13.2 \%$ in postpartum cows $(P<0.01$, Figure 1A). Similarly, Rabelo et al. (2003) reported that cows fed a prepartum high-energy diet (1.70 Mcal/kg of DM) had 19.8\% greater DMI (\% of BW) than cows fed a low-energydensity diet (1.58 Mcal/kg of DM).

The precalving HE diet had a significant carryover effect on the DMI in postpartum cows. We observed a trend for greater (diet, $P=0.08$ ) DMI in kilograms per day from $d-21$ to the day of parturition in cows fed the HE diet compared with control cows. The HE diet may have had better palatability, stimulating the DMI of the cows. In addition to palatability, hormonal, metabolic, and inflammatory changes may also influence the DMI of the cows during the transition period. The additive effects of several stimuli may affect cows' DMI; as a result, the factors that affect or surround the DMI of cows are very complex and largely not yet 
Table 3. Main effect of close-up dietary energy density and rumen-protected lysine supplementation on DMI, free fatty acids (FFA), BHB, BCS, and milk yield and composition during the transition period in dairy cows

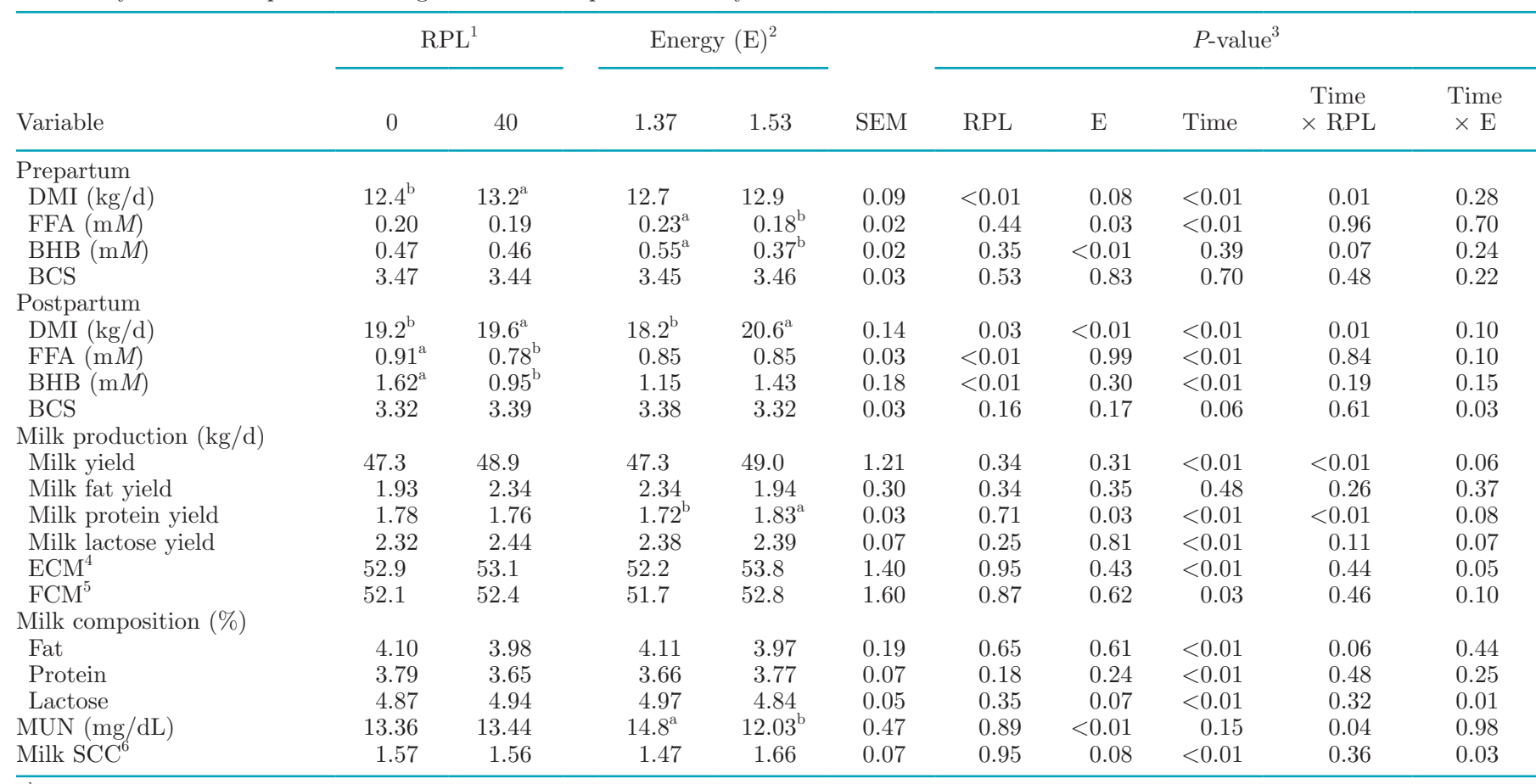

\footnotetext{
$\overline{\mathrm{a}, \mathrm{b}}$ Means from main effect in the same row with different superscripts are significantly different $(P<0.05)$ using the least significant difference method.

${ }^{1} \mathrm{RPL}=$ rumen-protected lysine (Ascor Chimici Srl, Beijing, China) top dressed on TMR at a total rate of $40 \mathrm{~g} /$ cow per day to deliver $9.68 \mathrm{~g}$ of metabolizable lysine to pre- and postpartum cows during the transition period.

${ }^{2}$ Close-up low-energy diet $(\mathrm{LE})=1.37 \mathrm{Mcal}$ of $\mathrm{NE}_{\mathrm{L}} / \mathrm{kg}$ of DM; close-up high-energy diet $(\mathrm{HE})=1.53 \mathrm{Mcal}$ of $\mathrm{NE} / \mathrm{kg}$ of DM.

${ }^{3}$ Time $=$ effect of time: $\mathrm{d}-21,-14,-7,0,3,7,14$, and 21 relative to calving day.

${ }^{4} \mathrm{ECM}=[12.82 \times$ fat yield $(\mathrm{kg})]+[7.13 \times$ protein yield $(\mathrm{kg})]+[0.323 \times$ milk yield $(\mathrm{kg})]$.

${ }^{5} \mathrm{FCM}=(0.4324 \times \mathrm{kg}$ of milk yield $)+(16.216 \times \mathrm{kg}$ of milk fat $)$.

${ }^{6}$ Milk SCC data were log-transformed.
}

understood (Litherland et al., 2011). Our result is in agreement with Holcomb et al. (2001), who reported that DMI was significantly increased in cows fed a lowforage diet compared with those fed a high-forage diet. Similarly, Rabelo et al. (2005) reported that cows fed high $\mathrm{NE}_{\mathrm{L}}$ of $1.7 \mathrm{Mcal} / \mathrm{kg}$ of DM from d -28 to calving had increased DMI and energy intake.

We found that supplementation of TMR with RPL significantly improved DMI in postpartum cows $(P=$ 0.03 , Figure 1B), which was similar to the findings of Swanepoel et al. (2010) who reported that the addition of RPL to the diet of mid-lactation cows tended to increase DMI. Feeding a precalving high-energy diet with bypass lysine ( $40 \mathrm{~g} /$ cow per day) increased prepartum DMI of cows $(14.9 \%, P<0.01)$ in that trial. The increased DMI in the current study could be due to greater MP and lysine intake, which reduced deficiency. Similarly, we found that RPL supplementation of the close-up diet increased DMI of cows compared with those in unsupplemented groups $(P=0.03)$. This finding may be explained by lysine contributing more to endogenous synthesis of carnitine, which would subsequently increase DMI. A previous study showed that as carnitine dose increased from 1 to $3 \mathrm{~g} / \mathrm{d}$, DMI tended to increase (Carlson et al., 2006). This finding demonstrated that the addition of RPL into TMR had a positive impact on DMI in both pre- and postpartum cows. In the present study, we found a positive effect on DMI by addition of RPL to a prepartum diet containing $15.1 \% \mathrm{CP}(P<0.01$, Figure 1E). Similarly, supplementation of RUP to increase dietary CP percentage to $19 \%$ CP improved DMI, milk production, and efficiency of protein metabolism in postpartum cows (Amanlou et al., 2017). Collectively, these results suggest that precalving energy diet and RPL played a significant role in DMI in the current study.

In general, the DMI of the cows is regulated by many complex factors, from the cellular level up to 
Table 4. Interaction effect of close-up dietary energy density and rumen-protected lysine (RPL; bypass lysine, Ascor Chimici Srl, Beijing, China) supplementation on DMI, free fatty acids (FFA), BHB, BCS, and milk yield and composition in dairy cows during the transition period

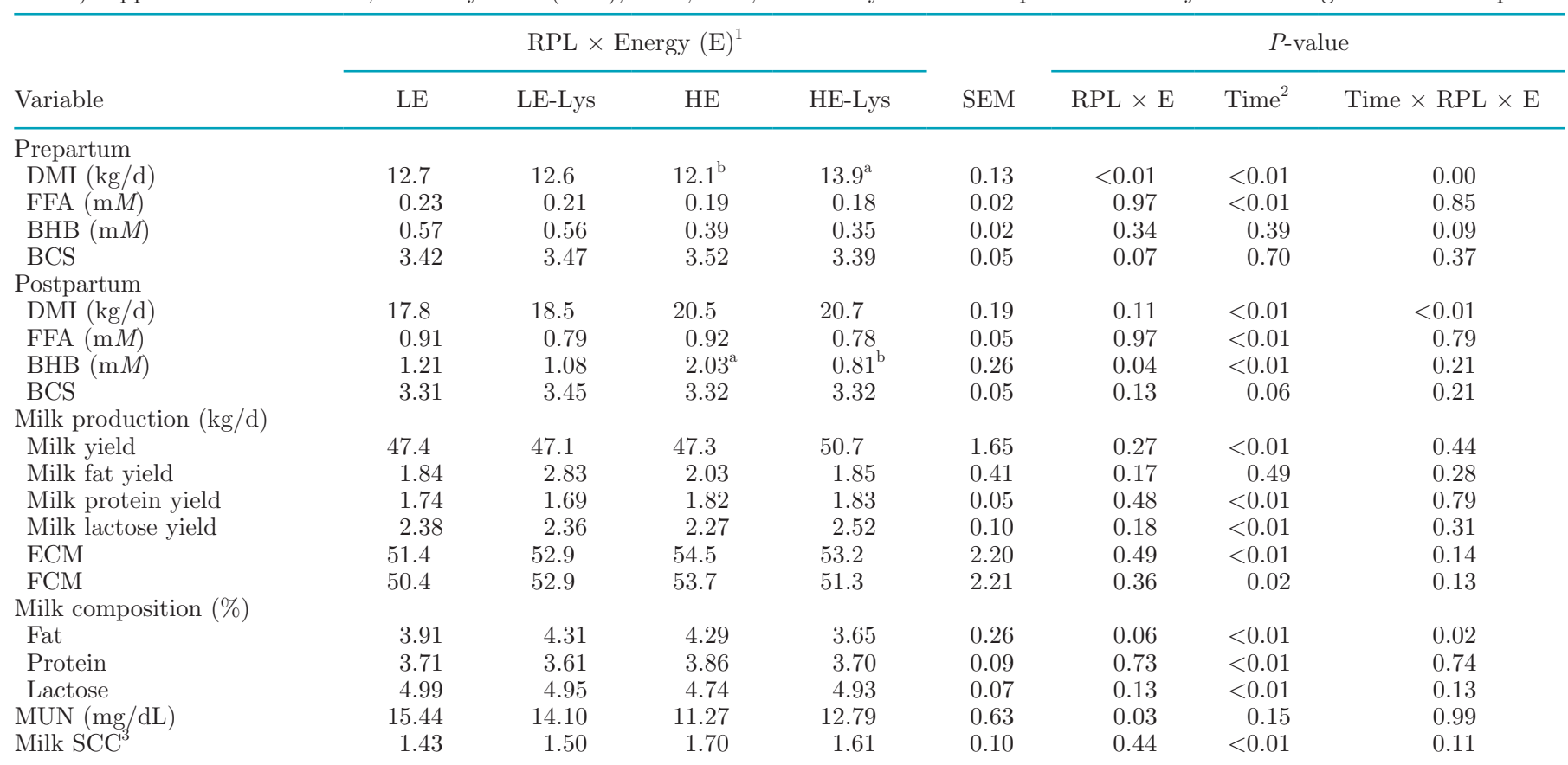

${ }^{\mathrm{a}, \mathrm{b}}$ Means from interactions in the same row with different superscripts are significantly different $(P<0.05)$ using the least significant difference method.

${ }^{1}$ Diets were high energy $\left(\mathrm{NE}_{\mathrm{L}}=1.53 \mathrm{Mcal} / \mathrm{kg}\right.$ of DM) with (HE-Lys) or without $(\mathrm{HE}) \mathrm{RPL}\left(40 \mathrm{~g} /\right.$ cow per day) or low energy $\left(\mathrm{NE} \mathrm{L}_{\mathrm{L}}=1.37 \mathrm{Mcal} /\right.$ $\mathrm{kg}$ of DM) with (LE-Lys) or without (LE) RPL.

${ }^{2}$ Time $=$ effect of time $(\mathrm{d}-21,-14,-7,0,-3,7,14$, and 21 relative to calving $)$.

${ }^{3}$ Milk SCC data were log-transformed.

environmental conditions (Allen, 2000). Although the mechanisms of hunger and satiety were thoroughly investigated in recent decades, factors surrounding the regulation of DMI are not fully understood yet (Allen, 2000; Kuhla et al., 2016).

\section{Effects on Pre- and Postpartum FFA Concentrations}

Negative energy balance and ketosis can be measured by NEFA and BHB concentrations in transition cows (Duffield et al., 2009). The reduction in blood glucose results in lower insulin levels, which trigger the fat mobilization process through lipolysis (Sordillo and Raphael, 2013). Our results show that feeding a precalving $\mathrm{HE}$ diet $(1.53 \mathrm{Mcal} / \mathrm{kg}$ of $\mathrm{DM})$ significantly decreased serum FFA concentrations in prepartum cows by $21.7 \%,(P=0.03$, Figure $2 \mathrm{C})$, but it did not affect FFA concentrations in postpartum cows. A close-up HE diet did not influence FFA concentration after calving, but the lower serum FFA concentrations for HE-fed cows reflected a more favorable energy status and indicated less adipose tissue mobilization during the prepartum period. Cows fed a high-energy-density diet $\left(1.7 \mathrm{NE}_{\mathrm{L}}\right.$
Mcal $/ \mathrm{kg}$ of $\mathrm{DM}$ ) had higher plasma concentrations of glucose and insulin, and a lower concentration of plasma NEFA on $\mathrm{d}-7$ relative to calving compared with cows fed low energy density $\left(1.57 \mathrm{NE}_{\mathrm{L}} \mathrm{Mcal} / \mathrm{kg}\right.$ of DM) ration (Rabelo et al., 2005).

Cows in the HE groups had numerically higher FFA concentrations in the first 2 wk after calving compared with cows in the LE group. Our data suggest that the precalving $\mathrm{HE}$ diet did not improve the negative energy balance and thereby increase body fat mobilization in postpartum cows. Prepartum feeding of high-energydensity diets has been previously shown to have a minor influence on metabolic status of cows postpartum (Rabelo et al., 2005).

Supplementation of RPL decreased serum FFA concentrations by $14.3 \%$ in postpartum cows $(P<0.01$, Figure 2D). In the present trial, the lowest FFA concentration $(0.54 \mathrm{~m} M)$ was observed on $\mathrm{d} 0$ (calving) in cows supplemented with RPL, whereas the highest FFA concentration $(1.08 \mathrm{mM})$ was found on d 14 after calving in cows fed precalving HE diet without RPL supplementation. Our data suggest that feeding only close-up HE rations predisposes postpartum cows to 
A

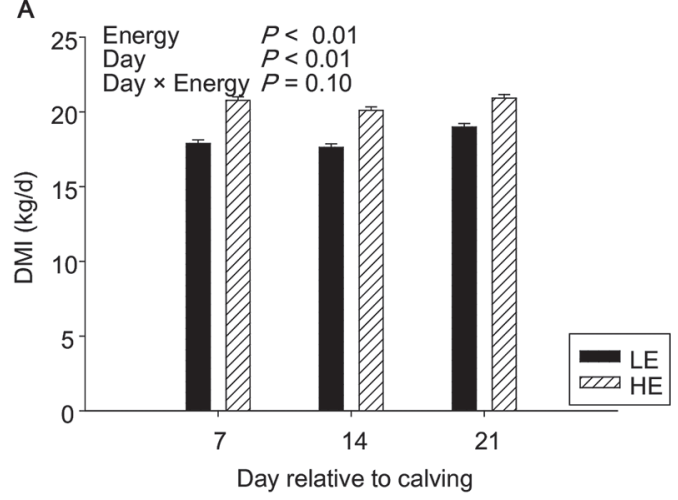

B

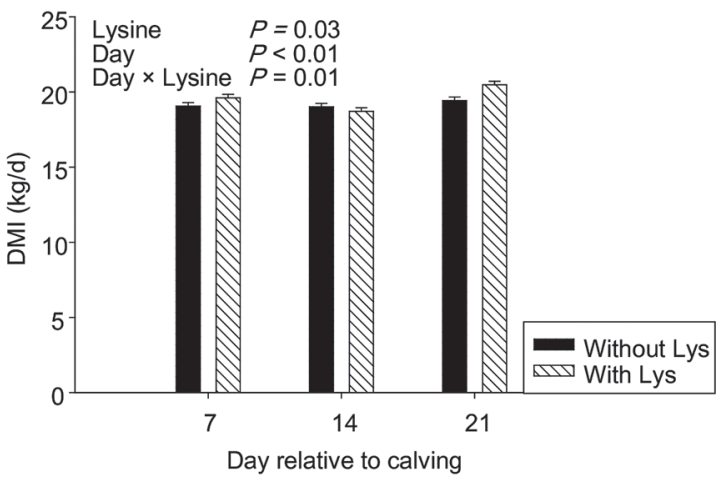

C
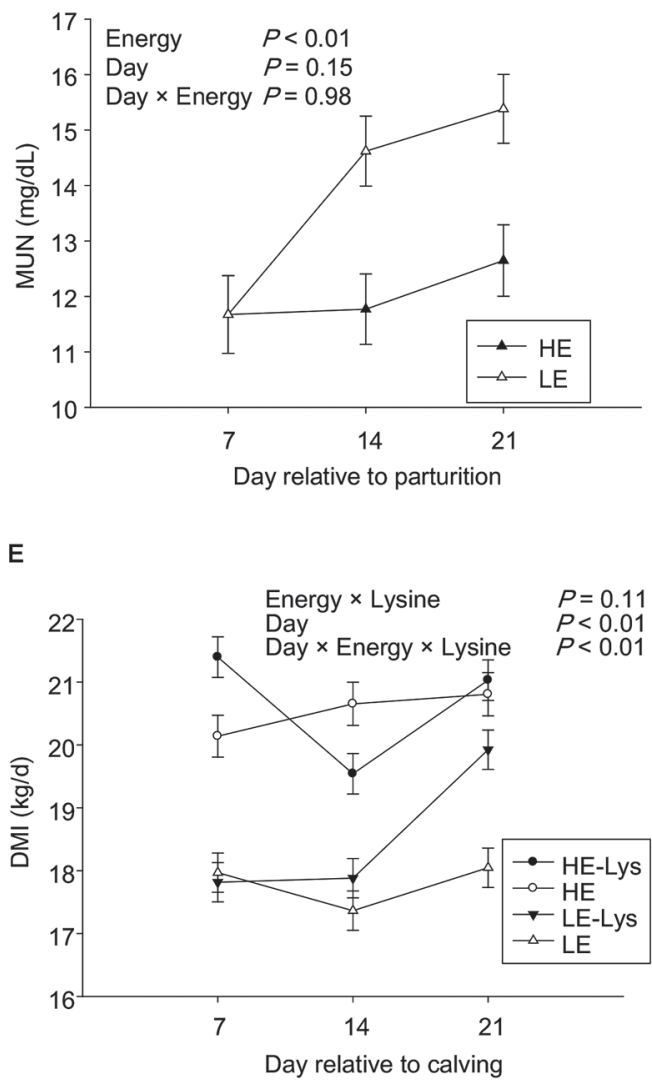

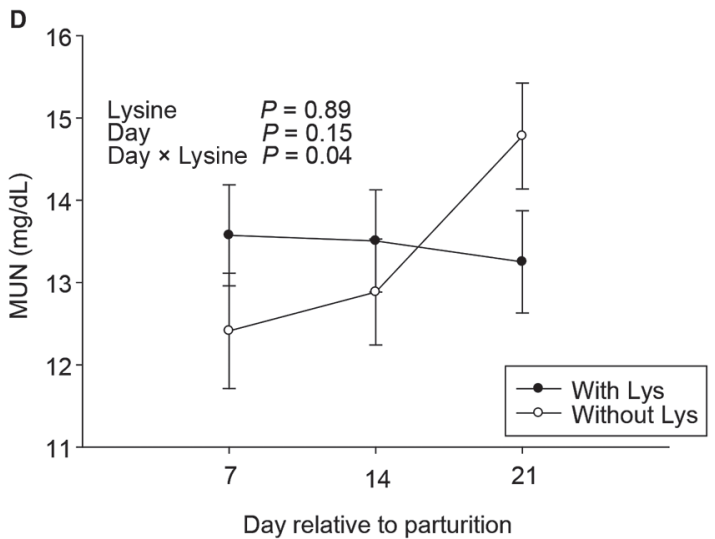

$\mathrm{F}$

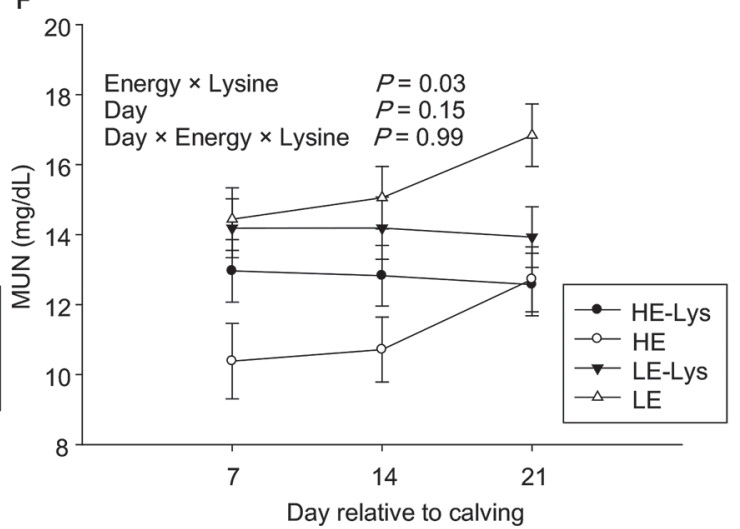

Figure 1. Effects of close-up dietary energy level and supplementing rumen-protected lysine (RPL, bypass lysine, Ascor Chimici Srl, Beijing, China) on DMI and MUN levels in dairy cows during the transition period. Diets were high energy $\left(\mathrm{NE}_{\mathrm{L}}=1.53 \mathrm{Mcal} / \mathrm{kg}\right.$ of DM) with $(\mathrm{HE}-\mathrm{Lys})$ or without (HE) RPL (40 g/cow per day) or low energy $\left(\mathrm{NE}_{\mathrm{L}}=1.37 \mathrm{Mcal} / \mathrm{kg}\right.$ of DM) with (LE-Lys) or without (LE) RPL. Values are means; error bars represent standard error.

have greater NEFA concentrations, as many authors have previously reported. Increased FFA concentrations in non-lysine-supplemented groups probably reflected a lower contribution of metabolizable lysine for carnitine synthesis to export FFA for $\beta$-oxidation compared with lysine-supplemented cows, which was probably also related to greater DMI with lysine and possible potentiation of anabolic signaling in tissues in response to lysine.

Similarly, Schulz et al. (2014) demonstrated that feeding late-gestation cows with a high proportion of concentrate lowered postpartum negative energy balance and increased NEFA concentrations. In the present study, we did not observe any interactions between 
A

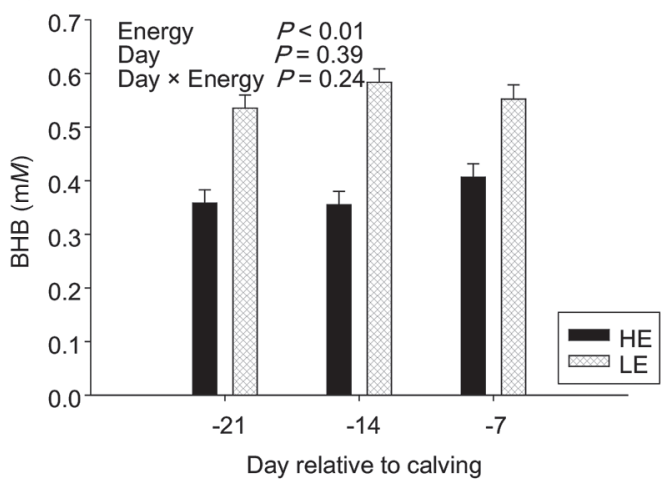

B

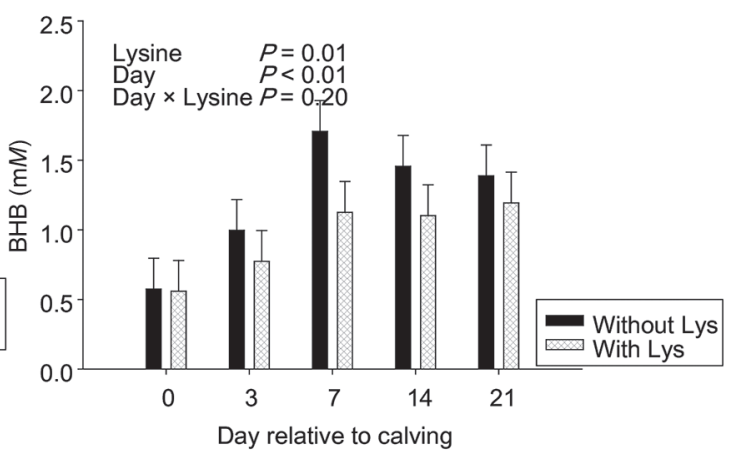

C

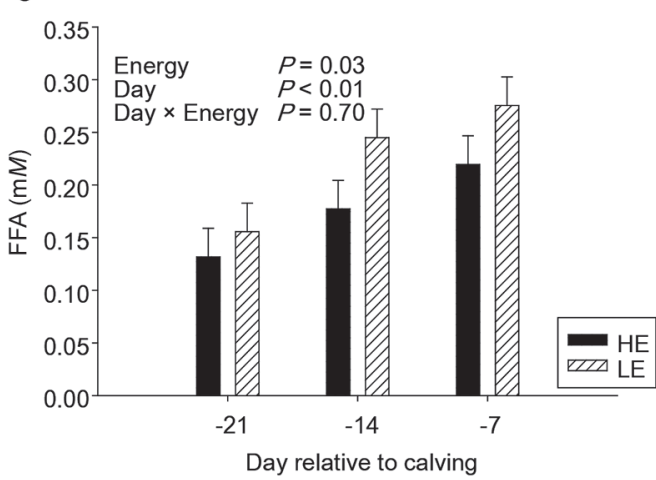

D

E

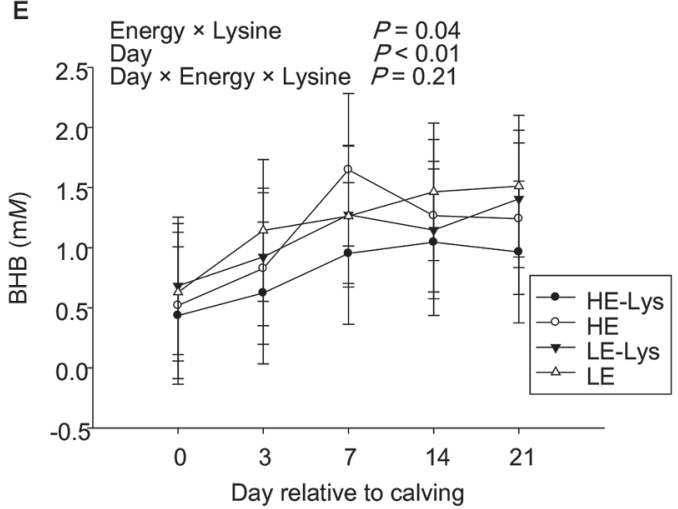

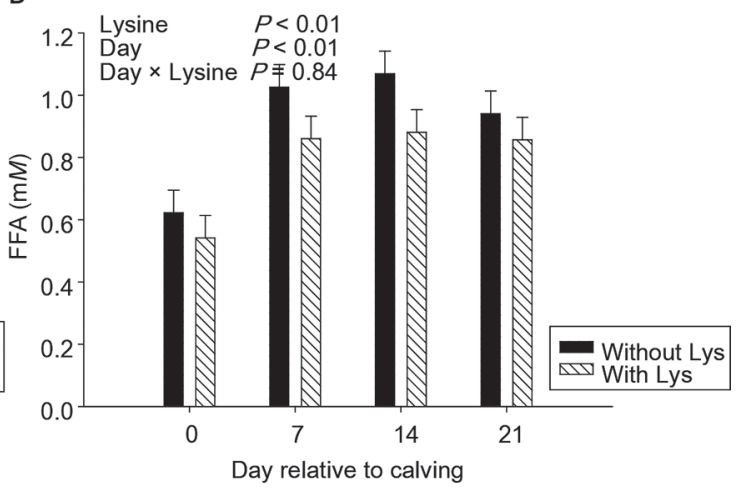

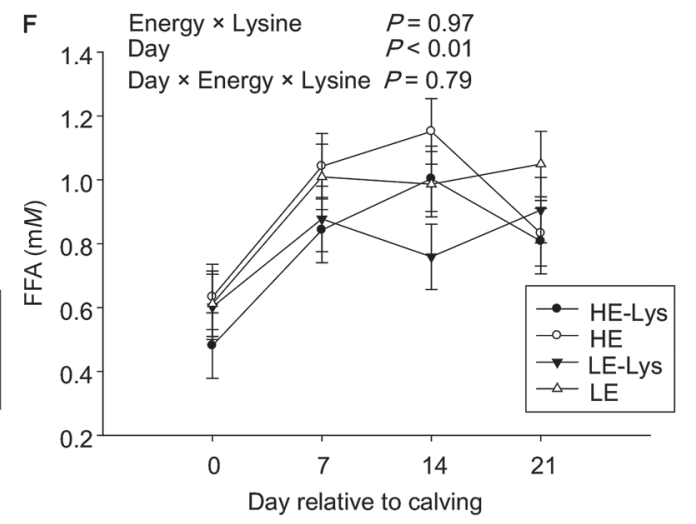

Figure 2. Effects of close-up dietary energy level and supplementing rumen-protected lysine (RPL; bypass lysine, Ascor Chimici Srl, Beijing, China) on BHB and free fatty acids (FFA) concentrations in dairy cows during the transition period. Diets were high energy $\left(\mathrm{NE}_{\mathrm{L}}=1.53 \mathrm{Mcal} /\right.$ $\mathrm{kg}$ of DM) with (HE-Lys) or without (HE) RPL ( $40 \mathrm{~g} / \mathrm{cow}$ per day) or low energy $\left(\mathrm{NE}_{\mathrm{L}}=1.37 \mathrm{Mcal} / \mathrm{kg}\right.$ of DM) with (LE-Lys) or without (LE) RPL. Values are means; error bars represent standard error.

precalving energy levels and RPL on FFA concentrations in pre- and postpartum cows $(P=0.97$, Figure $2 \mathrm{~F})$.

\section{Effects on BHB Concentrations}

Feeding a high-energy diet to dairy cows in the late prepartum period resulted in a significant increase in energy balance until the day of calving in a previous study (Rabelo et al., 2005). In the present study, precalving HE diets decreased plasma BHB concentrations by $32.7 \%$ in prepartum cows $(P<0.01$, Figure $2 \mathrm{~A})$. Similar to our results, plasma concentrations of BHB on d 21 were previously found to be $46 \%$ lower for cows fed high-energy diets compared with cows fed lowenergy diets (Rabelo et al., 2005). This finding may be due to a higher level of starch in a high-energy diet, which favors ruminal propionate (a glucogenic VFA) 
production and improves hepatic glucose production, which may in turn lead to lower fat mobilization and lower BHB concentrations in prepartum cows. Similarly, Grummer (1995b) reported that prepartum feeding of higher concentrate diets might provide more glucogenic propionate and reduce the incidence of ketosis around calving. These research results indicate that cows fed a precalving high-energy diet (low forage) were not mobilizing much energy from adipose tissue stores, which resulted in low BHB levels. In contrast, Douglas et al. (2006) reported that diets that contained a higher proportion of fiber increased DMI and prevented severe adipose tissue lipolysis. On the other hand, overfeeding a high-energy diet during the close-up period actually increases adipose tissue mobilization, leading to a greater negative energy balance (Graugnard et al., 2012). Walsh et al. (2007) reported that concentrations of BHB less than $2.6 \mathrm{mM}$ and greater than $1.4 \mathrm{mM}$ in the first week after calving and BHB levels $>1.0$ $\mathrm{m} M$ from $\mathrm{d} 7$ to 10 postpartum represented cows with subclinical ketosis. Duffield (2000) indicated that cows with BHB concentrations greater than $2.6 \mathrm{~m} M$ are defined as having clinical ketosis. In our study, cows fed the HE diet with RPL had lower BHB levels than cows with subclinical ketosis (Walsh et al., 2007). Moreover, cows fed the LE diet had higher BHB levels at calving compared with cows fed the HE diets. However, Miltenburg et al. (2018) reported that feeding $\mathrm{NE}_{\mathrm{L}}$ of 1.37 $\mathrm{Mcal} / \mathrm{kg}$ of DM from d 28 before calving to $5 \mathrm{wk}$ after calving affected the concentrations of both BHB and NEFA. Our results are consistent with those findings because feeding close-up cows a similar energy diet together with RPL resulted in a lower BHB concentration in postpartum cows.

A previous study showed that high $\mathrm{CP}$ levels in the diet of cows decreased the concentration of BHB (Amanlou et al., 2017), and our results were consistent with this decrease in postpartum BHB levels $(P=0.01$, Figure 2B). Energy and lysine supplementation had a significant interactive effect on BHB concentration in postpartum cows $(P=0.04$, Figure $2 \mathrm{E})$, but not in prepartum cows.

We hypothesize that RPL increased the bioavailability of carnitine (a methylated form of lysine), which consequently reduced NEFA concentration via $\beta$-oxidation, which may impair normal liver function. Decreasing NEFA concentration in the liver leads to lower mobilization of adipose tissue and a reduction of serum BHB concentrations. The liver appears to synthesize more glucose from propionate at d 21 postpartum compared with d 1 after calving or d 21 prepartum (Drackley et al., 2001). Additionally, Bauman and Elliot (1983) reported that the amount of mobilized tissue protein used as a source of amino acids for mammary metabolism and gluconeogenesis was relatively small from calving to peak lactation. The limited production of glucose during this period may have increased BHB levels in cows fed a prepartum LE diet.

\section{Effects on Milk Yield and Composition}

Precalving energy, RPL, and their interactions did not affect SCC, ECM, FCM, or milk, fat, or lactose yields in this study (Tables 3 and 4 ). In line with this, a previous study found that feeding dairy cows RPL to deliver $41 \mathrm{~g}$ of lysine/cow per day did not affect milk, true protein, or lactose yields in early lactation (Swanepoel et al., 2010). These findings support those reported by Paz et al. (2013) who did not observe any difference in milk yield or composition when RPL was supplemented into diets containing either distillers dried grains with soluble or wet corn gluten feed, respectively. Milk yield is less responsive to duodenal methionine and lysine supply than milk protein (NRC, 2001). In the current study, RPL did not affect milk yield, but it may have contributed to synthesis of milk protein. With findings similar to ours, Watanabe et al. (2006) reported that milk yield was unaffected when $16 \mathrm{~g} / \mathrm{d}$ intestinally absorbable lysine was added to the diet of early lactation cows. Feeding of 7 to $10 \mathrm{~g} / \mathrm{d}$ intestinally absorbable lysine had no effect on milk yield (Swanepoel et al., 2010). An approximately 2-kg increment in milk yield was observed when RPL was added to the diet of dairy cows to supply from 15 to 21 $\mathrm{g}$ of additional intestinally absorbable lysine compared with the control diet (Robinson et al., 2011).

In the present experiment, we did not observe milk yield differences when $9.68 \mathrm{~g} / \mathrm{d}$ of metabolizable lysine was delivered to pre- and postpartum cows $(P=$ 0.27, Figure 3F). Conversely, Robinson et al. (2011) reported that RPL increased milk yield, fat, true protein, and lactose yields. The discrepancy in milk yield and composition in response to RPL supplementation could be due to differences in the basal diets, methionine and lysine percentage of MP, and level of milk production (Swanepoel et al., 2010). In our trial, we found a tendency for increased milk production at wk 3 after parturition in response to the HE diet and supplementation with RPL $(P=0.06)$. This result indicated that high-producing cows positively responded to RPL, which agrees with the report of Bernard et al. (2014) who reported that cows producing greater than $36 \mathrm{~kg} / \mathrm{d}$ past peak lactation responded positively to supplementation of RPL. As DMI increased, the response to RPL appeared to support ECM yields over $45 \mathrm{~kg} / \mathrm{d}$ (Bernard et al., 2014). Similarly, we found that cows supplemented with RPL had numerically higher ECM than did unsupplemented cows. Conversely, low- 
producing cows (less than $36 \mathrm{k} \mathrm{g} / \mathrm{d}$ of milk) did not respond positively to RPL supplementation (Bernard et al., 2014). In another study, Robinson et al. (2011) found that supplementation of bypass lysine at $41 \mathrm{~g} / \mathrm{d}$ in early and mid-lactation cows improved milk yield from 48 to $50 \mathrm{~kg} / \mathrm{d}$. In contrast, we did not observe milk yield differences in response to supplementation of RPL during the transition period. However, RPL supplementation had a tendency to improve milk yield at wk 3 after calving, which supports the theory that bypass lysine supplementation improves the efficiency of MP used for milk protein synthesis and increases milk yield (NRC, 2001). In line with this, Amanlou et al. (2017) demonstrated that supplementation of RUP immediately after calving improved milk yield.

Somatic cell counts in the milk indicate the presence of an inflammatory response in the mammary gland (Schukken et al., 2003). In the current study, milk SCC were not affected by dietary energy levels or RPL or by their interactions $(P=0.44)$. However, the precalving LE diet had a tendency to reduce milk SCC compared with the precalving $\mathrm{HE} \operatorname{diet}(P=0.08$, Figure $3 \mathrm{C})$. We observed that time and energy interactions had a significant effect on milk SCC $(P=0.03)$. The highest SCC was recorded in cows fed the HE diet with RPL in the first week after calving and the lowest SCC was recorded in cows fed the LE diet only at wk 2 after calving $(P=0.44$, Figure $3 \mathrm{E})$. Supplementation of RPL did not affect milk SCC in this trial $(P=0.95$, Figure $3 \mathrm{D})$. In addition to mammary gland inflammation, cow productivity, health, parity, lactation stage, and breed of animal can also influence milk SCC concentrations (Alhussien and Dang, 2018).

The increase in milk SCC in cows fed the HE diet without RPL might be due to an influx of neutrophils into milk, as other associated factors, as was found by Graugnard et al. (2013) in precalving cows being overfed dietary energy during the dry period. High-producing cows are under a form of stress due to milk production and their immunity can become reduced, leading to more SCC in their milk (Mukherjee and Dang, 2011). Feeding RPL may contribute more support to highproducing cows, and they may not be under the same stresses as non-lysine-supplemented cows. Previous results demonstrated that immune suppression is often associated with a lack of energy or protein intake (Lean et al., 2013).

Lack of energy for optimum dietary protein utilization results in high MUN (Calsamiglia et al., 2010). Milk urea nitrogen content mainly depends on the nitrogen/energy ratio in the diet, but many other factors may affect ureagenesis. In this experiment, the precalving HE diet significantly decreased MUN by $18.7 \%$ ( $P$ $<0.01$, Figure 1C), compared with cows fed the LE diet. Adequate energy in the diet may reduce MUN via proper rumen function (ammonia assimilation into microbial crude protein), postruminally absorbed energy (fatty acids), and rumen-escaped carbohydrate. On the other hand, a ration low in fermentable carbohydrate can reduce microbial growth due to lower energy available to the microbes, leading to higher MUN values.

Interaction of precalving energy levels and RPL significantly affected the concentration of MUN $(P=0.03$, Figure 1F). Day and RPL interaction affected MUN ( $P$ $=0.04$, Figure 1D). Reduction of MUN when RPL was added to the HE diet could have occurred because of optimum utilization of nitrogen with a highly fermentable energy supply. A reduction in MUN concentration can be indicative of lower amino acid catabolism by the mammary gland and overall improved whole-body $\mathrm{N}$ efficiency (Broderick et al., 2008). Our observation of a decreased MUN with RPL addition to precalving HE diets suggested an improved efficiency of amino acid incorporation into protein, resulting in less amino acid deamination and urea synthesis.

Energy, RPL, and their interactions did not affect milk fat or lactose yields but feeding a precalving $\mathrm{HE}$ diet significantly increased milk protein yield by $6.5 \%$ compared with the control group $(P=0.03)$. The increase in milk protein yield in this study may be due to high starch levels in the HE diets, which favor glucose production to support milk protein synthesis.

Cows fed the LE diet with RPL had numerically higher milk fat yields compared with control group. The lower milk fat yield observed in cows fed LE without RPL supplementation was likely due to lower fiber digestibility, leading to reduced acetic and butyric acid production. Cows fed the HE diets with RPL also had numerically lower milk fat yields compared with controls. This finding may be due to a higher lysine percentage of MP in lysine-supplemented cows, as previous research has indicated that increasing the lysine percentage of MP also reduced milk fat when the methionine supply was deficient, or when the ratio of lysine to methionine was more than 3.0 (Swanepoel et al., 2010).

Lysine supplementation had no effect on milk protein yield $(P=0.71$, Figure $3 \mathrm{~B})$. Day and prepartum energy interaction tended to improve milk protein yield $(P=$ $0.08)$, especially at wk 2 after calving; but cows fed LE had lower milk protein levels at wk 3. A precalving HE diet significantly affected protein yield $(P=$ 0.03 , Figure $3 \mathrm{~A}$ ). Cows fed the HE diet supplemented with RPL had numerically higher lactose yields than unsupplemented cows.

Energy, bypass lysine, and their interactions did not affect BCS (Tables 3 and 4). In our study, prepartum energy density did not affect BCS during pre- and post- 


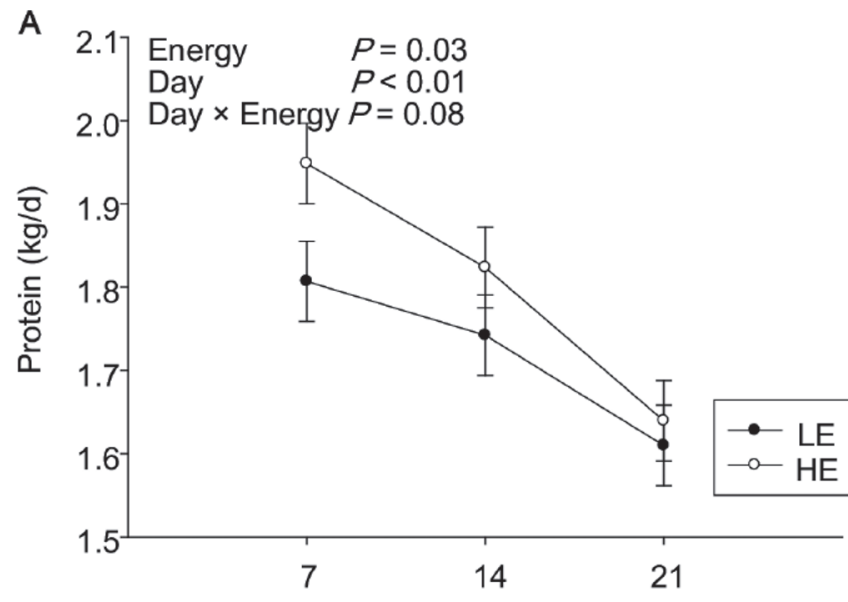

Day relative to parturition

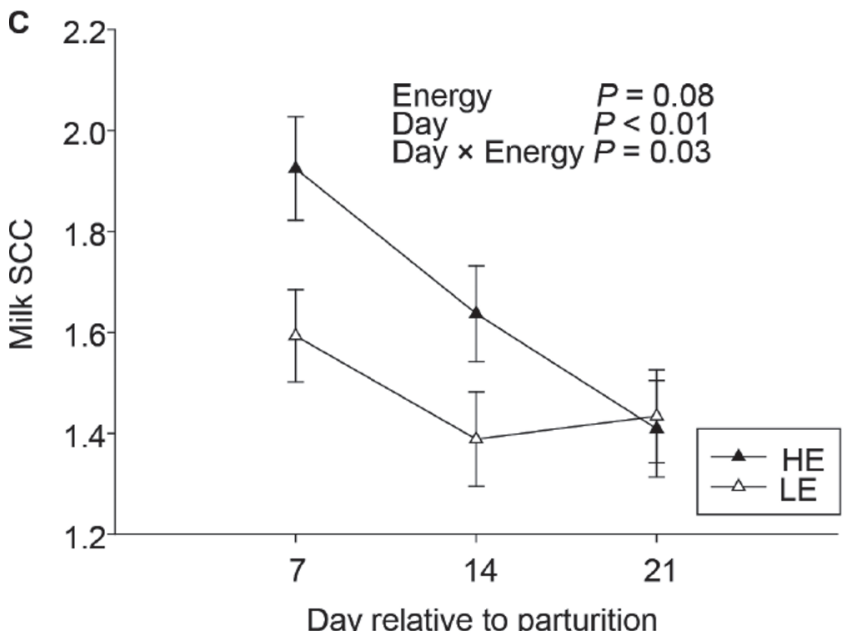

E

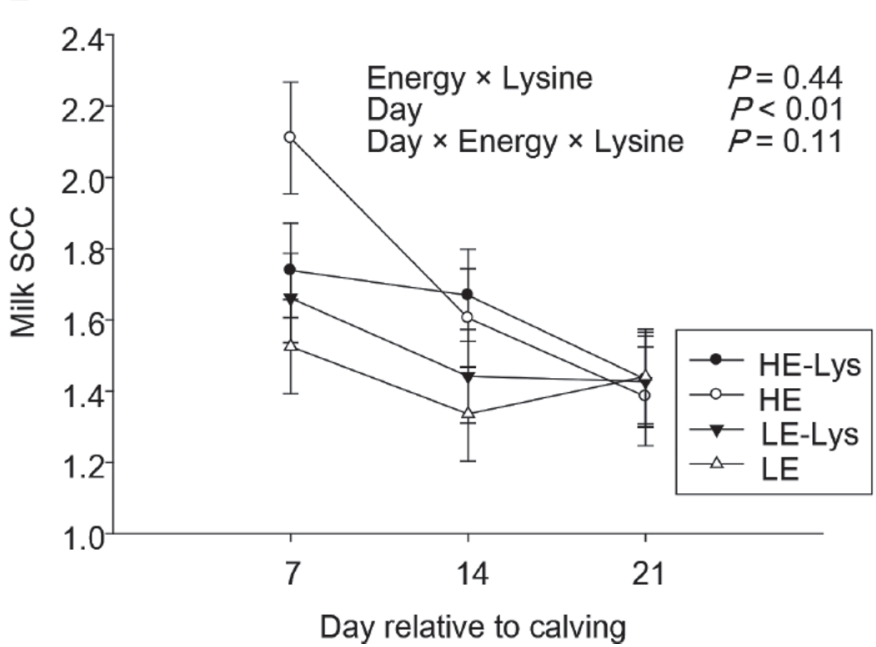

B

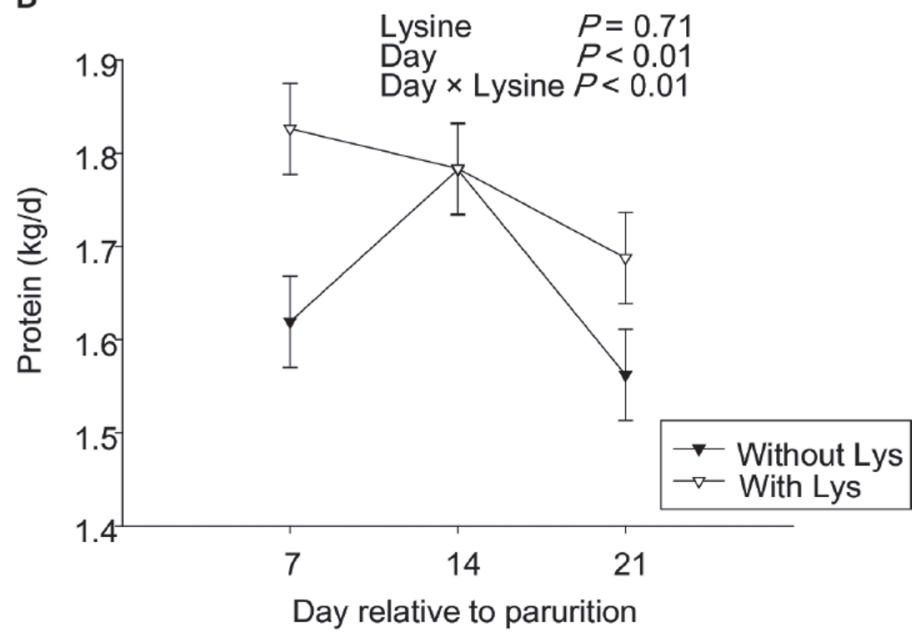

D

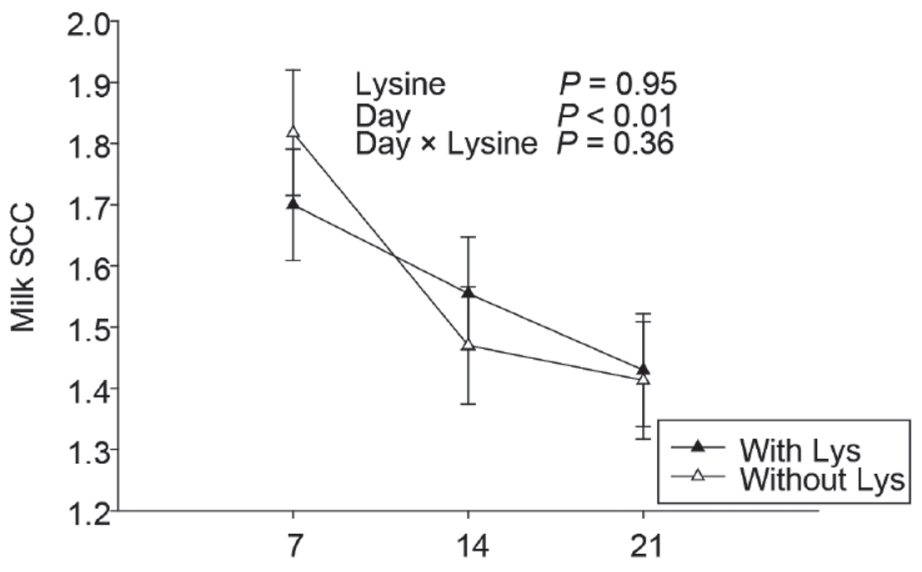

Day relative to parturition

F

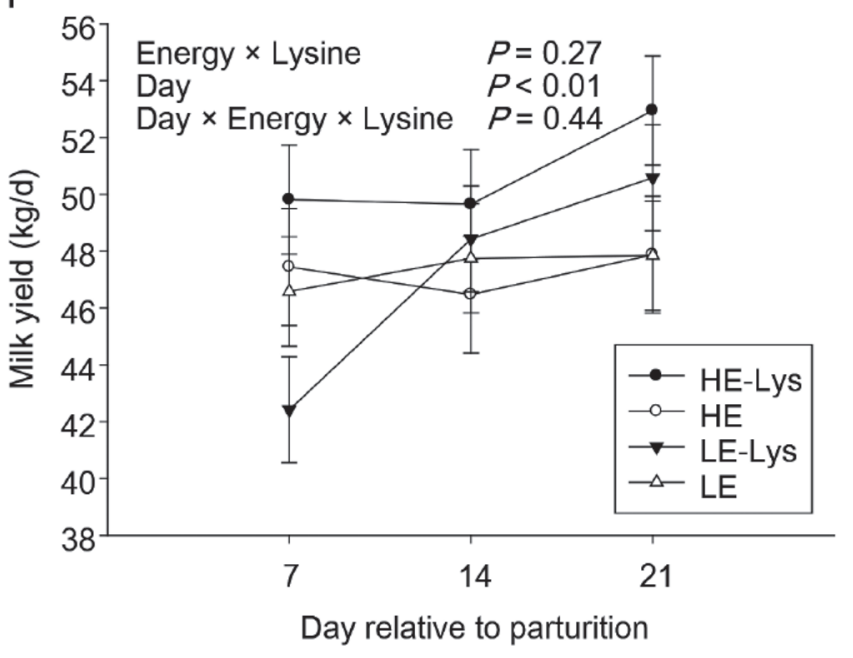

Figure 3. Effects of close-up dietary energy level and supplementing rumen-protected lysine (RPL; bypass lysine, Ascor Chimici Srl, Beijing) on milk yield, protein yield, and milk SCC during the transition period. Diets were high energy $\left(\mathrm{NE}_{\mathrm{L}}=1.53 \mathrm{Mcal} / \mathrm{kg}\right.$ of DM) with $(\mathrm{HE}-\mathrm{Lys})$ or without (HE) RPL (40 g/cow per day) or low energy $\left(\mathrm{NE}_{\mathrm{L}}=1.37 \mathrm{Mcal} / \mathrm{kg}\right.$ of DM) with (LE-Lys) or without (LE) RPL. Values are means; error bars represent standard error. 
partum periods. Similarly, Huang et al. (2014) reported that prepartum feeding energy density (1.62 vs. 1.29 $\mathrm{Mcal} / \mathrm{kg}$ of DM) did not impact pre- and postpartum BCS. Supplementation of rumen-protected lysine to the transition diet did not affect BCS (Swanepoel et al., 2010; Robinson et al., 2011). Similarly, we did not observe any significant difference in BCS in response to rumen-protected lysine in this study.

\section{CONCLUSIONS}

Feeding a precalving HE diet decreased both FFA and $\mathrm{BHB}$ concentrations in prepartum but not postpartum cows. An HE diet alone (1.53 Mcal $/ \mathrm{kg}$ of DM) increased DMI, lowered MUN levels, tended to increase milk SCC, and reduced milk lactose percentage in postpartum cows. Cows supplemented with RPL had a tendency to produce higher milk yields from wk 1 to wk 3 after calving compared with unsupplemented cows. The interaction of precalving $\mathrm{HE}$ diet and RPL decreased BHB levels and MUN concentrations and tended to lower milk fat percentage in postpartum cows compared with the control group. We concluded that feeding RPL at a rate of $40 \mathrm{~g} / \mathrm{cow}$ per day, which delivered $9.68 \mathrm{~g} / \mathrm{d}$ of intestinally absorbable lysine, had beneficial effects on increasing DMI and reducing FFA and BHB concentrations in postpartum dairy cows during the transition period.

\section{ACKNOWLEDGMENTS}

We are very grateful to Gary Crow from the University of Manitoba (Canada) for his great contribution to the statistical analysis. We thank the National Key Research and Development Program of China (2018YFD0501600), the Agriculture Science and Technology Innovation Program (ASTIP-IAS07), the Chinese Academy of Agricultural Science and Technology Innovation project (CAAS-XTCX2016011-01), and the Beijing Dairy Industry Innovation Team (BAIC062019) for providing financial and technical support for this study.

\section{REFERENCES}

Alhussien, M. N., and A. K. Dang. 2018. Milk somatic cells, factors influencing their release, future prospects, and practical utility in dairy animals: An overview. Vet. World 11:562-577.

Allen, M. S. 2000. Effects of diet on short-term regulation of feed intake by lactating dairy cattle. J. Dairy Sci. 83:1598-1624.

Amanlou, H., T. A. Farahani, and N. E. Farsuni. 2017. Effects of rumen undegradable protein supplementation on productive performance and indicators of protein and energy metabolism in Holstein fresh cows. J. Dairy Sci. 100:3628-3640.

AOAC International. 2000. Official Methods of Analysis. 17th ed. AOAC International, Gaithersburg, MD.
Ardaillon, P., and C. Franzoni. 1992. Enzymatically degradable coating compositions for feed additives intended for ruminants. RhonePoulenc Santé, assignee. U.S. Pat. No. 5,098,718.

Bauman, D., and J. Elliot. 1983. Control of nutrient partitioning in lactating ruminants. Biochemistry of lactation. Pages 437-462 in Biochemistry of Lactation. T. B. Mepham, ed. Elsevier, Amsterdam, the Netherlands.

Bernard, J., P. Chandler, C. Sniffen, and W. Chalupa. 2014. Response of cows to rumen-protected lysine after peak lactation. Prof. Anim. Sci. 30:407-412.

Broderick, G. A., N. D. Luchini, S. M. Reynal, G. A. Varga, and V. A. Ishler. 2008. Effect on production of replacing dietary starch with sucrose in lactating dairy cows. J. Dairy Sci. 91:4801-4810.

Calsamiglia, S., A. Ferret, C. Reynolds, N. B. Kristensen, and A. Van Vuuren. 2010. Strategies for optimizing nitrogen use by ruminants. Animal 4:1184-1196.

Carlson, D. B., N. B. Litherland, H. M. Dann, J. C. Woodworth, and J. K. Drackley. 2006. Metabolic effects of abomasal L-carnitine infusion and feed restriction in lactating Holstein cows. J. Dairy Sci. 89:4819-4834.

Citil, M., M. Karapehlivan, H. M. Erdogan, R. Yucayurt, E. Atakisi, and O. Atakisi. 2009. Effect of orally administered L-carnitine on selected biochemical indicators of lactating Tuj-ewes. Small Rumin. Res. 81:174-177.

Douglas, G. N., T. R. Overton, H. G. Bateman II, H. M. Dann, and J. K. Drackley. 2006. Prepartal plane of nutrition, regardless of dietary energy source, affects periparturient metabolism and dry matter intake in Holstein cows. J. Dairy Sci. 89:2141-2157.

Drackley, J. K. 1999. ADSA Foundation Scholar Award. Biology of dairy cows during the transition period: The final frontier. J. Dairy Sci. 82:2259-2273.

Drackley, J. K., T. R. Overton, and G. N. Douglas. 2001. Adaptations of glucose and long-chain fatty acid metabolism in liver of dairy cows during the periparturient period. J. Dairy Sci. 84(Suppl.):E100-E112.

Duffield, T. 2000. Subclinical ketosis in lactating dairy cattle. Vet. Clin. North Am. Food Anim. Pract. 16:231-253.

Duffield, T. F., K. D. Lissemore, B. W. McBride, and K. E. Leslie. 2009. Impact of hyperketonemia in early lactation dairy cows on health and production. J. Dairy Sci. 92:571-580.

Edmonson, A. J., I. J. Lean, L. D. Weaver, T. Farver, and G. Webster. 1989. A body condition scoring chart for Holstein dairy cows. J. Dairy Sci. 72:68-78.

Faul, F., E. Erdfelder, A. Buchner, and A.-G. Lang. 2009. Statistical power analyses using $G^{*}$ Power 3.1: Tests for correlation and regression analyses. Behav. Res. Methods 41:1149-1160.

Goff, J. P. 2006. Major advances in our understanding of nutritional influences on bovine health. J. Dairy Sci. 89:1292-1301.

Graugnard, D. E., M. Bionaz, E. Trevisi, K. M. Moyes, J. L. SalakJohnson, R. L. Wallace, J. K. Drackley, G. Bertoni, and J. J. Loor. 2012. Blood immunometabolic indices and polymorphonuclear neutrophil function in peripartum dairy cows are altered by the level of dietary energy prepartum. J. Dairy Sci. 95:1749-1758.

Graugnard, D. E., K. M. Moyes, E. Trevisi, M. J. Khan, D. Keisler, J. K. Drackley, G. Bertoni, and J. J. Loor. 2013. Liver lipid content and inflammometabolic indices in peripartal dairy cows are altered in response to prepartal energy intake and postpartal intramammary inflammatory challenge. J. Dairy Sci. 96:918-935.

Grummer, R. R. 1995b. Impact of changes in organic nutrient metabolism on feeding the transition dairy cow. J. Anim. Sci. 73:28202833.

Grummer, R. R., D. G. Mashek, and A. Hayirli. 2004. Dry matter intake and energy balance in the transition period. Vet. Clin. North Am. Food Anim. Pract. 20:447-470.

Holcomb, C. S., H. Van Horn, H. Head, M. Hall, and C. Wilcox. 2001. Effects of prepartum dry matter intake and forage percentage on postpartum performance of lactating dairy cows. J. Dairy Sci. 84:2051-2058.

Huang, W., Y. Tian, Y. Wang, A. Simayi, A. Yasheng, Z. Wu, S. Li, and Z. Cao. 2014. Effect of reduced energy density of close-up diets 
on dry matter intake, lactation performance and energy balance in multiparous Holstein cows. J. Anim. Sci. Biotechnol. 5:30.

Jacobs, S. 2002. Practical experiences with L-carnitine. Lohmann Inf. Int. 26:21-24.

Kuhla, B., C. C. Metges, and H. M. Hammon. 2016. Endogenous and dietary lipids influencing feed intake and energy metabolism of periparturient dairy cows. Domest. Anim. Endocrinol. 56:S2-S10.

Lean, I. J., R. Van Saun, and P. J. DeGaris. 2013. Energy and protein nutrition management of transition dairy cows. Vet. Clin. North Am. Food Anim. Pract. 29:337-366.

Litherland, N. B., H. M. Dann, and J. K. Drackley. 2011. Prepartum nutrient intake alters palmitate metabolism by liver slices from peripartal dairy cows. J. Dairy Sci. 94:1928-1940.

Martel, C. A., E. C. Titgemeyer, L. K. Mamedova, and B. J. Bradford. 2011. Dietary molasses increases ruminal $\mathrm{pH}$ and enhances ruminal biohydrogenation during milk fat depression. J. Dairy Sci. 94:3995-4004.

Miltenburg, C. L., T. F. Duffield, D. Bienzle, E. L. Scholtz, and S. J. LeBlanc. 2018. The effect of prepartum feeding and lying space on metabolic health and immune function. J. Dairy Sci. 101:52945306.

Mukherjee, J., and A. K. Dang. 2011. Immune activity of milk leukocytes during early lactation period in high and low yielding crossbred cows. Milchwissenschaft 66:384-388.

NRC. 2001. Nutrient Requirements of Dairy Cattle. 7th rev. ed. Natl. Acad. Press, Washington, DC.

Paz, H. A., M. J. de Veth, R. S. Ordway, and P. J. Kononoff. 2013. Evaluation of rumen-protected lysine supplementation to lactating dairy cows consuming increasing amounts of distillers dried grains with solubles. J. Dairy Sci. 96:7210-7222.

Pirestani, A., M. Aghakhani, S. Tabatabaei, G. Ghalamkari, and F. Baharlo. 2011. Effects of dietary L-carnitine and choline chloride compound on reproduction indices and udder immune system in Holstein dairy cattle. Pages 59-61 in 2011 International Conference on Life Science and Technology. IPCBEE vol. 3. IACSIT Press, Singapore.

Rabelo, E., R. L. Rezende, S. J. Bertics, and R. R. Grummer. 2003. Effects of transition diets varying in dietary energy density on lactation performance and ruminal parameters of dairy cows. J. Dairy Sci. 86:916-925.

Rabelo, E., R. L. Rezende, S. J. Bertics, and R. R. Grummer. 2005. Effects of pre- and postfresh transition diets varying in dietary energy density on metabolic status of periparturient dairy cows. J. Dairy Sci. 88:4375-4383.

Robinson, P., E. DePeters, I. Shinzato, and H. Sato. 2006. Rumen lysine escape, rumen fermentation, and productivity of early lactation dairy cows fed free lysine. Anim. Feed Sci. Technol. 128:31-41.
Robinson, P., N. Swanepoel, I. Shinzato, and S. Juchem. 2011. Productive responses of lactating dairy cattle to supplementing high levels of ruminally protected lysine using a rumen protection technology. Anim. Feed Sci. Technol. 168:30-41.

Schukken, Y. H., D. J. Wilson, F. Welcome, L. Garrison-Tikofsky, and R. N. Gonzalez. 2003. Monitoring udder health and milk quality using somatic cell counts. Vet. Res. 34:579-596.

Schulz, K., J. Frahm, U. Meyer, S. Kersten, D. Reiche, J. Rehage, and S. Dänicke. 2014. Effects of prepartal body condition score and peripartal energy supply of dairy cows on postpartal lipolysis, energy balance and ketogenesis: An animal model to investigate subclinical ketosis. J. Dairy Res. 81:257-266.

Shug, A. L., M. J. Schmidt, G. T. Golden, and R. G. Fariello. 1982 The distribution and role of carnitine in the mammalian brain. Life Sci. 31:2869-2874.

Sordillo, L. M., and W. Raphael. 2013. Significance of metabolic stress, lipid mobilization, and inflammation on transition cow disorders. Vet. Clin. North Am. Food Anim. Pract. 29:267-278.

Swanepoel, N., P. Robinson, and L. Erasmus. 2010. Amino acid needs of lactating dairy cows: Impact of feeding lysine in a ruminally protected form on productivity of lactating dairy cows. Anim. Feed Sci. Technol. 157:79-94.

Vailati-Riboni, M., G. Farina, F. Batistel, A. Heiser, M. D. Mitchell, M. A. Crookenden, C. G. Walker, J. K. Kay, S. Meier, J. R. Roche, and J. J. Loor. 2017. Far-off and close-up dry matter intake modulate indicators of immunometabolic adaptations to lactation in subcutaneous adipose tissue of pasture-based transition dairy cows. J. Dairy Sci. 100:2334-2350.

Van Soest, P. J., J. B. Robertson, and B. A. Lewis. 1991. Methods for dietary fiber, neutral detergent fiber, and nonstarch polysaccharides in relation to animal nutrition. J. Dairy Sci. 74:3583-3597.

Vaz, F. M., and R. J. Wanders. 2002. Carnitine biosynthesis in mammals. Biochem. J. 361:417-429.

Walsh, R. B., J. S. Walton, D. F. Kelton, S. J. LeBlanc, K. E. Leslie, and T. F. Duffield. 2007. The effect of subclinical ketosis in early lactation on reproductive performance of postpartum dairy cows. J. Dairy Sci. 90:2788-2796.

Watanabe, K., A. H. Fredeen, P. H. Robinson, W. Chalupa, W. E. Julien, H. Sato, H. Suzuki, K. Katoh, and Y. Obara. 2006. Effects of fat coated rumen bypass lysine and methionine on the performance of dairy cows fed a diet deficient in lysine and methionine. J. Anim. Sci. 77:495-502. 